\title{
LAURIAN SOMEȘAN ÎNTRE ZENIT ȘI NADIR, ADICĂ ÎNTRE EMULAȚIE IDENTITARĂ - ÎMPLINIRE PROFESIONALĂ ȘI EPURARE-MARGINALIZARE ÎN PERIOADA ALTERITĂȚII PROLETCULTISTE
}

\begin{abstract}
ALEXANDRU PĂCURAR1
ABSTRACT. - Laurian Someșan between the High and the Low, between Individual Merit-Professional Fulfilment and Exclusion through Cleansing from the Academic Realm, during the Proletkultistic Political Changes. Professor Laurian Someșan, a geographer formed under the leadership of George Vâlsan, the one who laid the foundations of the Cluj School of Geography, experienced a sinuous professional development due to the hardship of the times, namely the fact that Romania was assigned to the sphere of Soviet influence.

Getting himself noticed as early as on the desks of the faculty by the scholar George Vâlsan, Laurian Someșan became, in the third year of college, a preparatory assistant at the Institute of Geography of the "King Ferdinand I" University of Cluj, where he advanced in his career to the teaching degree of Senior Lecturer. Stopped in his professional ascent for obscure reasons, Laurian Someșan was transferred to the Academy of High Commercial and Industrial Studies of Cluj which was in its refuge at Brassov, due to the cession of the northwest Transylvania, to which Romania had been forced. There he reached the top of the professional hierarchy due to his won merits; he also had the position of Rector of this Academy (1947-1948).

After the abusive abolition of the monarchy, Professor Laurian Someșan gradually met the avatars of marginalization, his removal from higher education culminating with the prison regime and forced labour that was imposed to him (15 August 1952-April 1954) by the oppressive regime.

The author tries to explain the resorts that have been at the basis of these accumulated abuses.

Keywords: "King Ferdinand I" University of Cluj, Academy of High Commercial and Industrial Studies of Cluj, Rector, Soviet occupation, sovietization, prison regime, forced labour.
\end{abstract}

\footnotetext{
1 Babeş-Bolyai University, Faculty of Geography, Clinicilor Street, no. 5-7, Cluj-Napoca-400006,
} Romania, e-mail: alexandru.pacurar@ubbcluj.ro 
Perioada „brașoveană” a lui Laurian Someșan a fost „pregătită” înainte ca profesorul să se stabilească în orașul de la poalele Tâmpei de către parcæ, zeițele Nona, Decima și Morta, cele care ne stabilesc destinul. Acceptarea lui la Academia de Înalte Studii Comerciale și Industriale Carol II din Cluj în anul 1939, în locul profesorului Sabin Opreanu care revenea în sânul membrilor Institutului de Geografie al Universității Regele Ferdinand I din Cluj, așa cum șia dorit cu ardoare, l-a marcat definitiv pe Laurian Someșan, din toate punctele de vedere. Profesional, pentru că în această nu mai puțin prestigioasă instituție românească de învățământ superior românesc își va vedea împlinită cariera didactică prin accederea la gradul de profesor universitar, agregat, de la 1 martie 1943, apoi definitiv, trei ani mai târziu. Administrativ, pentru că ocupă cel mai înalt post, acela de rector al Academiei Comerciale, numit în toamna anului 1947, demnitate pe care a păstrat-o un an, până după reforma de tip stalinist a învățământului românesc din 3 august 1948. Se cuvine amintit aici că, o perioadă a refugiului (septembrie 1940 - martie 1943), Laurian Someșan a „navetat” între Sibiu, la Catedra de Geografie generală și umană a Facultății de Științe a Universității clujene, de sub conducerea profesorului Sabin Opreanu, care a fost refugiată acolo, unde ocupa postul de șef de lucrări, și Brașov, unde suplinea postul de profesor al Catedrei de Geografie economică din cadrul Academiei Comerciale, aflată în refugiu acolo. Accederea sa în corpul profesoral al Academiei Comerciale din Cluj-Brașov, care a ființat în orașul de la poalele Tâmpei până în anul 1950, l-a obligat să se stabilească în orașul de la poalele Tâmpei, fiindcă orașul i-a plăcut, atât lui cât și familiei; urbe deschisă, plurietnică și pluriculturală, care avea multe asemănări cu locul său de baștină, plaiurile năsăudene, și suficiente asemănări cu Clujul, orașul în care s-a format și a evoluat atât de promițător la început, Brașovul „l-a adoptat” pe Laurian Someșan care avea să rămână definitiv legat de el.

\section{LAURIAN SOMEȘAN, RECTOR ÎN CONTRA-TIMP AL ACADEMIEI DE ÎNALTE STUDII COMERCIALE ȘI INDUSTRIALE REGELE MIHAI I DIN BRAȘOV}

Activitatea profesorului Laurian Someșan în cadrul Academiei de Înalte Studii Comerciale și Industriale Regele Mihai I din Cluj-Brașov a fost apreciată deopotrivă de studenți, colegi universitari, colaboratori, precum și de autoritățile administrative ale Ministerului Educației Naționale, din moment ce în toamna anului 1947 a fost numit rector al ei. Momentul desemnării sale în fruntea acestei prestigioase instituții de învățământ superior economic românesc, a doua din țară după aceea de la București, a venit însă într-un moment deosebit de greu, România aflându-se practic sub ocupația Armatei 
Roșii, în plin proces de erodare și de disoluție a valorilor sale democratice și naționale, de stalinizare, care a fost marcată de episoade dramatice de epurare a învățământului românesc în general, și a celui superior în special, de cadrele sale cele mai valoroase sub aspect profesional și național-patriotic. 0 întrebare firească se naște: numirea geografului Laurian Someșan ca rector al Academiei Comerciale a fost o încercare de rezistență din partea autorităților românești, de temporizare a procesului de stalinizare a instituției sau, dimpotrivă, a fost încă un pas spre stalinizare, spre promovarea submediocrităților? Greu de răspuns; documentele arhivistice care ne-au stat la îndemână, precum și destinul tragic al profesorului Laurian Someșan, inclină balanța afirmativă, aceea de încercare de temporizare, căci de o stopare a procesului de stalinizare a țării nici nu putea fi vorba în acele circumstanțe geopolitice.

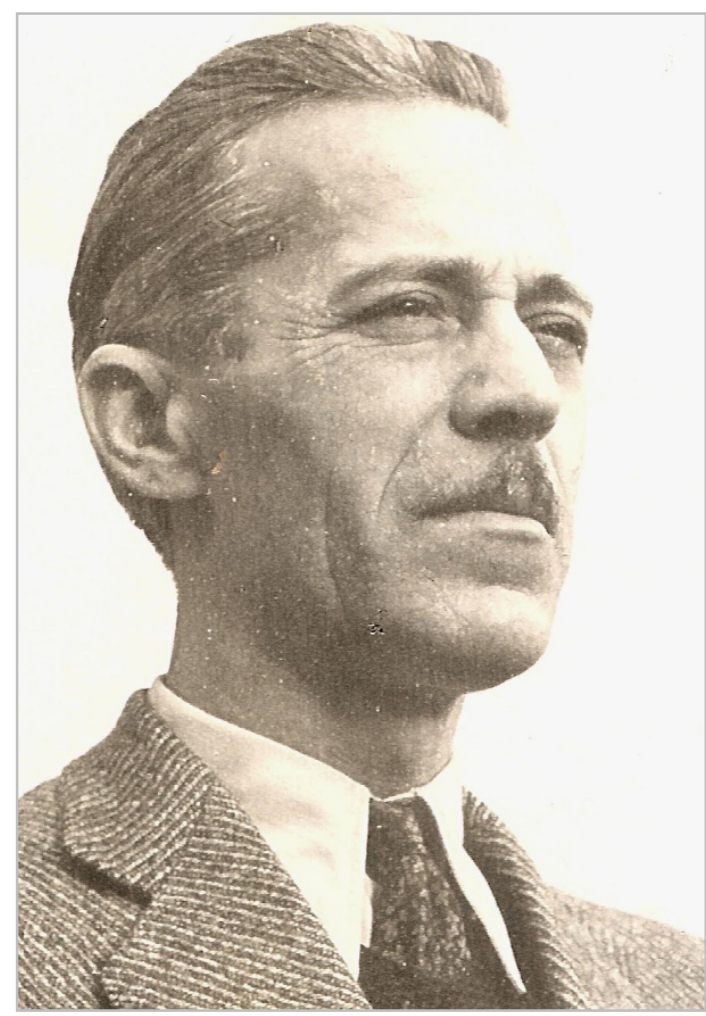

Profesorul Laurian Someșan în perioada rectoratului său la Academia de Înalte Studii Comerciale și Industriale Regele Mihai I din Brașov (1947-1948).
Printre primele documente arhivistice identificate care dovedesc calitatea de rector al Academiei Comerciale din Brașov a profesorului Laurian Someșan, este acela al convocării Comisiei de examen de admitere pentru anul I, datat 12 noiembrie 1947, adresat profesorilor Dumitru Voina, Olimpiu Boitoș, Augustin Tătaru, cel care i-a succedat ca rector în perioada 1948-1949, și Sabin Cioranu. În convocator se menționează că „Avem onoarea $a$ vă ruga să binevoiți a vă întruni în Comisie, joi 13 noiembrie 1947, ora 12, la Rectorat, pentru stabilirea rezultatelor de la examenul de admitere în anul I".

În anul fatidic 1947, acela al decapitării României prin silirea abdicării forțate a Regelui Mihai I, de către o bandă de criminali aserviți Moscovei, și a proclamării ilegale a RPR de către un Parlament ilegitim, anul universitar 1947/ 1948 la Academia Comercială din Brașov (se luase 
hotărârea „de sus” ca ea să nu se mai întoarcă la Cluj!), s-a deschis la 16 noiembrie, la ora 17 „precis”!, în sala festivă a Curții de Apel din Brașov. La „deschiderea solemnă a cursurilor”, „Domnișoarele și Domnii studenți sunt rugați cu toții a lua parte”, se menționează în „Aviz”, festivitatea desfășurându-se încă după tipicul obișnuit, astfel că aceasta a început cu „oficierea slujbei religioase”, fiind urmată de cuvântarea Rectorului, și apoi a unui student merituos din anul I. Ca element nou în decalogul desfășurării deschiderii anului universitar, de factură stalinistă, a fost introducerea cuvântării unui al doilea student, din partea Uniunii Naționale a Studenților din România (U.N.S.R.), dovadă a politizării mediului universitar! Această pseudo-organizație studențească manipulată de komisarii sovietici, din „centrul” Brașov al ei, a adresat la 29 octombrie 1947 rectorului Academiei Comerciale, înainte de deschiderea cursurilor, „rugămintea” ca, „în cadrul sărbătorirei zilei de 7 noiembrie a.c., să delegați din partea Rectoratului doi Domni profesori, care să vorbească despre: 1) Semnificația zilei, cu sublinierea revoluției Octombriste; 2) Legăturile culturale și economice cu URSS". Pe această cerere nerușinată, rectorul Academiei Comerciale, profesorul Laurian Someșan, s-a văzut nevoit să pună următoarea rezoluție, la 1 noiembrie 1947: „Pentru subiectul 1.) se deleagă Dl. Prof. A[ugustin] Tătaru, pentru subiectul 2., se deleagă Dl. Prof. O[vidiu] Boitoș". Avem în față dovada unei metode de pătrundere în conștiința publicului românesc a unor evenimente străine ei, în cazul de față al revoluției bolșevice care, în fapt, n-a avut nici un element măreț! Pentru adevărata „față” a ei, vezi excelenta monografie a lui Orlando Figes - Revoluția Rusă, 1891-1924: tragedia unui popor (2016, op. cit.). Câteva zile mai târziu, Laurian Someșan a comunicat la 3 noiembrie, profesorului Octavian Boitoș, că „a fost delegat să vorbească” în cadrul sărbătoririi zilei de 7 noiembrie despre „Legăturile culturale și economice cu URSS”, menționând: „conferința nu va depăși cadrul unei jumătăți de oră”! Iată cum rectorul a redus la jumătate timpul afectat conferinței cerut de către organizația studențească „revoluționară și democratică”, adică a stopat atât cât i-a stat în putere, intoxicarea cu minciuni sovietice a publicului românesc tânăr și lipsit de experiență! Este și aceasta o dovadă de rezistență în fața molohului sovietic... Profesorul Boitoș, în deplină înțelegere tacită, a notificat că „am primit” însărcinarea rectorală.

Conform noilor uzanțe puse în practică de guvernul Dr. Petru Groza, aservit Moscovei, după deschiderea Noului An universitar 1947/1948, profesorul Laurian Someșan, în calitatea lui de rector al Academiei Comerciale din Brașov, a trimis ministrului Educației Naționale Ștefan Voitec și prim-ministrului Dr. Petru Groza, telegrame prin care exprimă recunoștința studenților și profesorilor (sic!), asigurându-i de „întregul lor devotament de luptă ce se duce pentru consolidarea democrației în universitate”, precum și că „vor lupta din răsputeri pentru triumful integral al democrației românești"; începuse procesul dedublării conștiinței, al dublului limbaj și al folosirii „limbii de lemn”! 
Ca urmare a procesului de „democratizare” amintit mai sus, Oficiul Academic, organismul care se ocupa de editarea și publicarea cursurilor studențești din fiecare universitate românească, era pe cale să se transforme, în acest sens cerându-i-se rectorului să ofere „cât mai neîntârziat indicații despre felul cum înțelege Academia să organizeze în viitor acest serviciu de editare și difuzare a cursurilor", din cadrul așa-zisei noi „Asistențe studențești”. În fapt era vorba de o formă inedită de control strict, pus sub cenzura sovietică, a editării cursurilor și manualelor universitare, un nou mijloc de îngrădire a libertății de gândire și de exprimare. Chiar în aceste condiții, au fost cadre didactice precum Leon Diculescu care, fidel libertăților universitare, a solicitat „procurarea unei hărți a Italiei cu regiunile ei economice”, fiind necesară „studenților care urmează cursul de limbă italiană”. Rectorul Laurian Someșan căruia i-a fost adresată solicitarea, a pus pe cerere următoarea rezoluție, la 12 noiembrie 1947: „Se aprobă”, însărcinând pe asistentul Stancu de la Catedra de Geografie economică „să întocmească schița hărții solicitate”.

După cum majoritatea cadrelor didactice căutau să se mențină în legătură cu curentul de idei și cu evoluția social-economică din Europa Occidentală, spațiul nostru cultural natural spre care începuse să se instituie blocada sovietică - , să nu uităm că la Fulton, în fața studenților, Winston Churchill spusese că „o cortină de fier s-a instaurat și desparte Europa în două”, - o altă categorie de profesori se iviseră, clamând „introducerea studiului Limbii și Literaturii Ruse (pe același plan de egalitate al limbilor moderne) [sic!] pe lângă Academia de IInalte Studii Comerciale și Industriale", propunere supusă atenției rectorului Laurian Someșan de către Covalschi Teodor, profesor titular la Liceul Andrei Șaguna. Sub ocupație sovietică, în plin proces de stalinizare, rectorul a pus rezoluția: „se va înainta Consiliului Profesoral”. Acesta, la 20 noiembrie 1947, „a hotărât să ceară referințe de la Liceul Andrei Șaguna cum predă acel curs” profesorul solicitant, precum și „avizul de la Sindicatul Corpului didactic al învăţământului secundar". În final, la 22 noiembrie, Consiliul Profesoral al Academiei Comerciale s-a adresat A.R.L.U.S. pentru a-i recomanda o persoană „titrată care cunoaște bine limba rusă", menționând că este dispus să aprobe „un curs facultativ de rusă, până ce Ministerul va înființa prin buget o catedră de limba rusă"; se încerca astfel o rezistență, invocând legea...

Pe lângă presiunile exercitate în rusificarea planului de învățământ și politizarea studenților, la care Laurian Someșan a trebuit să facă față în calitatea lui de rector, el s-a văzut nevoit să rezolve spinoasa problemă a spațiului de învățământ, care se acutizase odată cu ocupația sovietică, prin preluarea și reconstrucția Liceului Honterus (Liceul evanghelic cum se numise până atunci), unitate școlară de elită a comunității germane din Brașov, care fusese deposedată de toate bunurile, iar etnicii germani, în mare parte, deportați în URSS. Preluarea acestui liceu este dovedită de ordinea de zi ale ședințelor Consiliului Profesoral al Academiei Comerciale, din perioada 12-22 noiembrie 1947. 
Parcă nu au fost îndeajuns aceste probleme, fiindcă li s-au adăugat altele, grave și ele, de natură financiară legate de stabilizarea leului, care a survenit la 15 august 1947, și căreia rectorul Laurian Someșan a trebuit să-i facă față. Se cuvine amintit aici că introducerea leului nou, în schimbul a 20000 lei vechi, a avut ca scop spolierea claselor sociale medii și superioare. Astfel, salariații și muncitorii au putut preschimba 3 milioane de lei vechi; țăranii, 5 milioane, la care se puteau adăuga încă 2,5 milioane pentru cei care își achitaseră cotele la stat (imposibil de achitat!); 1,5 milioane lei vechi au putut preschimba persoanele neîncadrate în câmpul muncii. În acest sens, la 20 noiembrie 1947, Laurian Someșan s-a adresat Direcției Contabilității din Ministerul Educației Naționale, solicitând „instrucțiuni cu privire la reevaluarea inventarului, în urma stabilizării leului".

Acestor probleme grave, rectorul Academiei Comerciale și întreg corpul profesoral au trebuit să le facă față în același timp cu rezolvarea unor probleme stringente de ordin social, care vizau deopotrivă pe studenți, cadre didactice și persoane cu care instituția era în relații de colaborare. Astfel, un grup de studenți din anul III, „băieți săraci lipsiți de mijloace materiale, fapt care ne-a obligat să ne angajăm în câmpul muncii", cum s-au autodescris, au solicitat la 18 noiembrie 1947 modificări în orar, pentru a putea să participe la laboratoare și la orele de Educație fizică, ținând cont de faptul că sunt angajați ca să se poată întreține, doleanță care a găsit o deplină înțelegere la Laurian Someșan. Tot prin hotărârea rectorului, Consiliului Profesoral îi sunt înaintate la 13 noiembrie 1947 cererile de retribuire pentru activități prestate în calitate de delegat-director al Oficiului Academic a asistentului Gheorghe Stoica, sau a dr. Ioan Tocitu, de asemenea asistent, pentru activitatea depusă în cadrul Secției sportive a Oficiului Academic. Aceste intervenții dovedesc salarizarea precară, de tip sovietic, care începuse să afecteze nivelul de trai al cadrelor didactice...

Pe lângă precaritatea salarizării corpului didactic universitar, acesta se lovea, aidoma locuitorilor întregii țări, cu lipsa cronică a produselor de primă necesitate, alimentare și nealimentare, motiv pentru care consumul acestora a fost raționalizat și cartelat. Aceste produse se aflau sub un control strict, așa cum o dovedește declarația rectorului Academiei Comerciale, profesorul Laurian Someșan, adresată Oficiului Economic Municipal Brașov, în care „subsemnata Academie” a făcut cunoscut că „am eliberat personalului nostru următoarele cartele în alimente [sic!, de alimente, s.n.] pe luna noiembrie, după tipul lor, conform tabelului specificativ anexat", a unui număr de 118 cartele! Ocupantul sovietic a devalizat și jefuit bogata Țară Românească... Sub acest ocupant atât de nesătul, sau rechiziționat și naționalizat fără discernământ multe proprietăți, inclusiv locative, așa cum o dovedește cererea văduvei de război Laufer Cecilia, „proprietara imobilului din strada Nicolae Iorga 26" din Brașov, care, adresându-i-se rectorului Academiei Comerciale, a solicitat o locuință în propriul său imobil rechiziționat, ca să poată supraviețui fiind lipsită de alte venituri. 
Referindu-se la realizările tatălui său în calitate de rector al Academiei de Înalte Studii Comerciale și Industriale Regele Mihai I din Brașov, Maria Someșan, a consemnat pentru posteritate (2011, op. cit., pp. 13-14): „În calitate de rector a reușit, între altele, să rezolve o problemă acută cu care se lupta instituția: lipsa de spațiu [...]. Într-un singur an, noul rector a procurat fondurile necesare ridicării unei aripi noi de clădire, bazându-se nu doar pe sumele alocate de Minister, ci și pe sponsorizările obținute de la foști studenți ai Academiei, deveniți între timp industriași sau mari comercianți (naționalizările nu avuseseră încă loc)", precizând că „este aripa dinspre str. Postăvarului, în care din 1950, după mutarea la Iași a Academiei Comerciale, a funcționat Facultatea de Mecanică a nou înființatei Politehnici din Brașov. Înalții copaci care străjuiesc azi clădirea, Laurian Someșan i-a plantat! A fost însă cântecul de lebădă al activității sale universitare, care va fi întreruptă pentru foarte mulți ani de vicisitudinile epocii staliniste".

Din cele prezentate mai sus, probate cu documentele arhivistice, activitatea ca rector a lui Laurian Someșan a fost diversă, supusă presiunilor ideologice și sociale, de multe ori incomensurabile, la care a trebuit să facă față, în timpul unui regim de ocupație opresiv, complet străin românilor. La fel de dramatică a fost solicitarea doamnei Herta Ulmann, co-proprietara imobilului din strada Regina Maria nr. 62, rechiziționat „în favorul Academiei Comerciale pentru instalarea Căminului de Studente", care a rugat în mod stăruitor ca în propriul ei imobil, să i se pună la dispoziție „un apartament din două camere pentru locuit”. Iată ce distorsiuni și tensiuni a indus în societatea românească ocupantul sovietic, înainte și în timpul rectoratului lui Laurian Someșan.

Despre atmosfera toxică indusă de sovietici la Brașov, voi oferi o mostră de "umanism" de tip nou, apelând la amintirile din copilărie ale Steluței Pestrea Suciu: „În primii ani de după război, să fie prin 1949-1950, rușii se aflau în oraș. Unchiul meu, locatarul de la parter [este vorba de casa din strada Pictor Pop, nr. 2, s.n.], primise de la niște prieteni din București un pui de căprioară, tare sprințar, botezat Iți-Miți-Riți-Piți. În scurt timp a devenit vedeta cartierului. $\mathrm{Nu}$ trecea cineva pe stradă să n-o strige și să n-o privească admirativ. Într-una din zile, niște ruși care locuiau într-o casă de pe strada Dobrogeanu-Gherea - după ce proprietarii au fost evacuați -, în drum spre Spitalul Militar au împușcat căprioara. Au intrat în curte, fără reținere, au târât-o în stradă, unde au părăsit-o. Cruzimea comportamentului a șocat, să folosesc un eufemism, a făcut să răbufnească sentimentele față de sovietici, deloc cordiale, din cauza evenimentelor politice" (2011, op. cit., p. 252). 

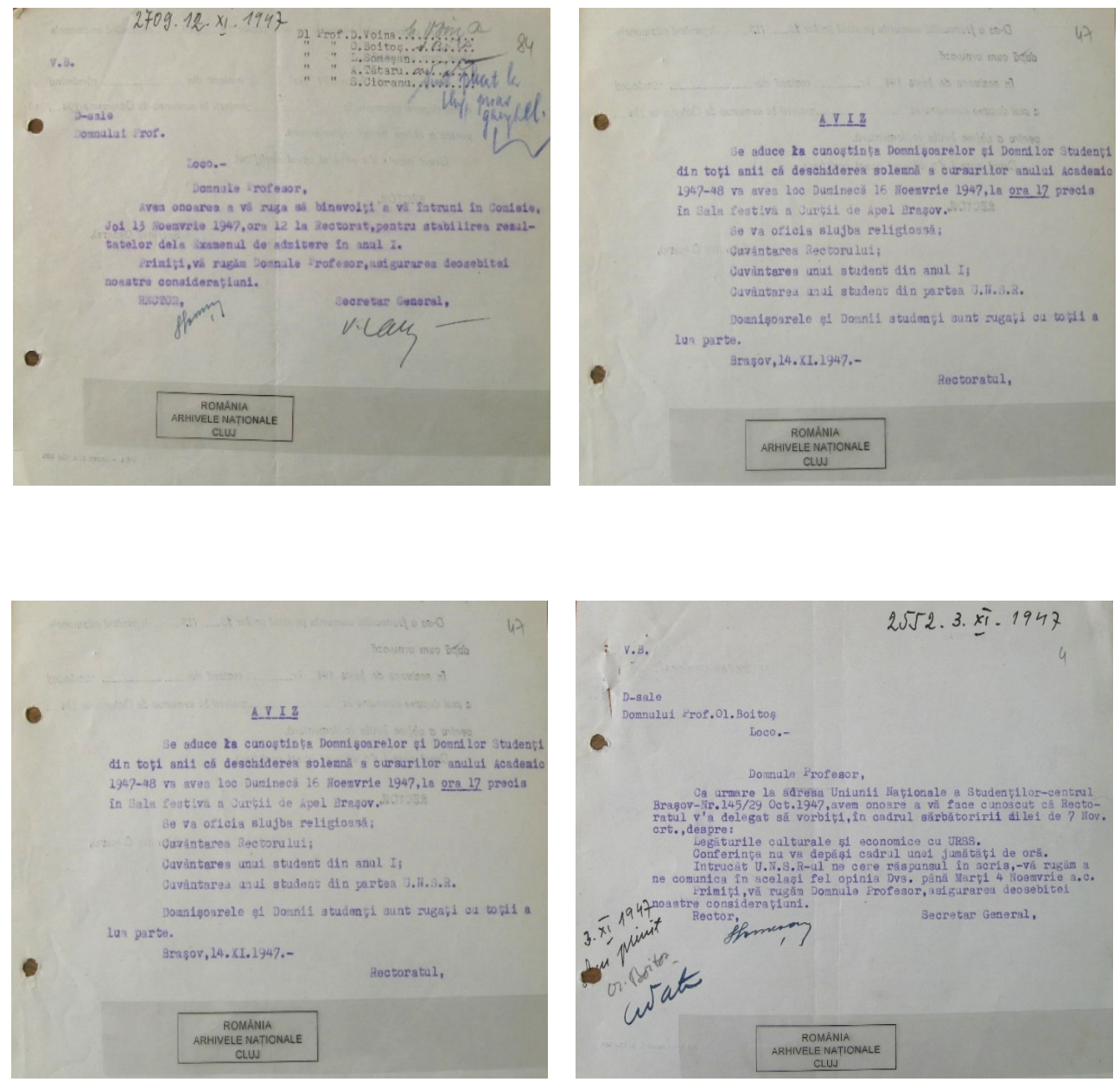

Documente relative la activitatea ca rector al Academiei de Înalte Studii Comerciale și Industriale din Brașov a profesorului Laurian Someșan, privitoare la deschiderea anului universitar 1947/1948 și la impunerea sărbătoririi zilei de 7 noiembrie. 

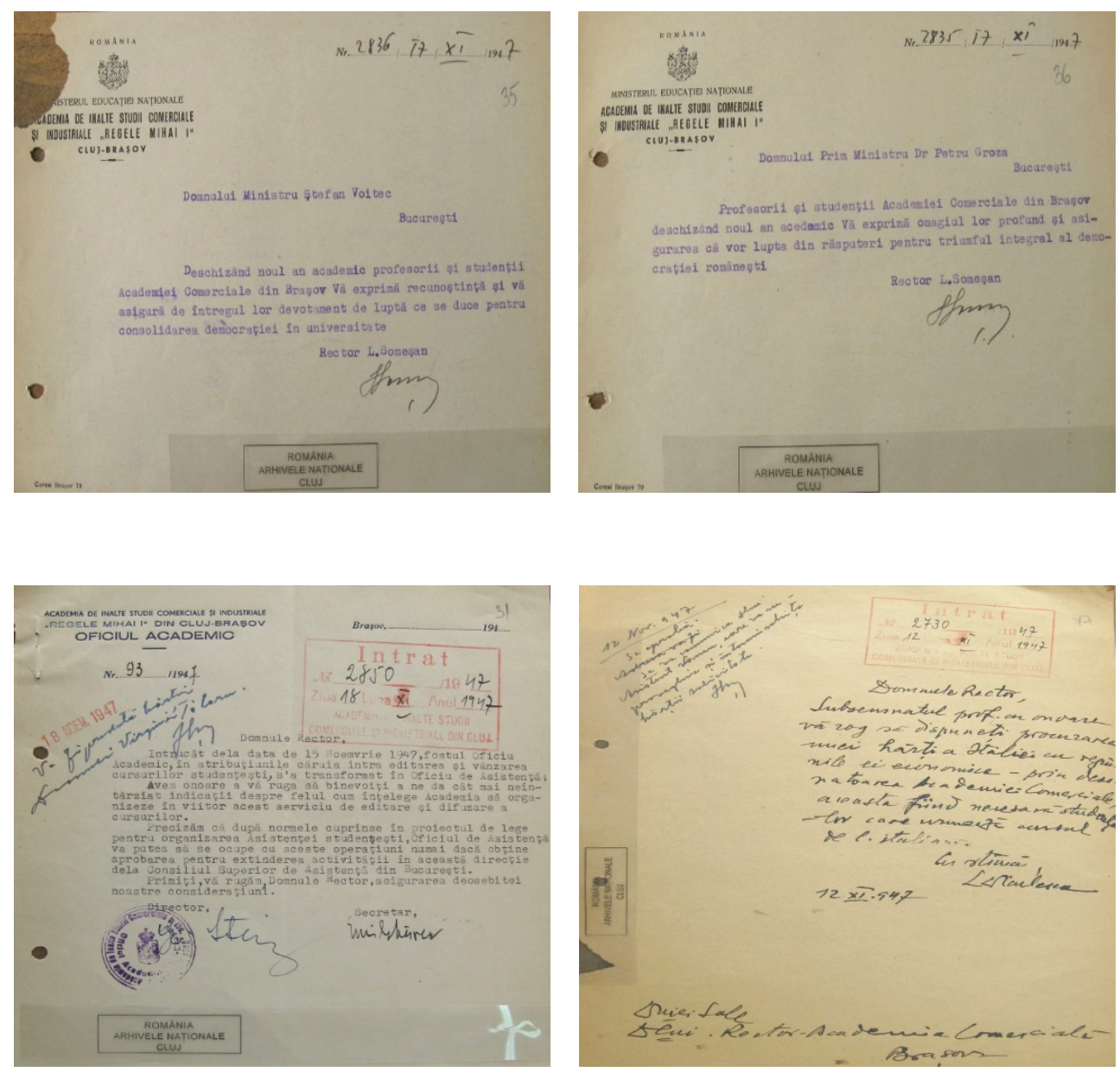

Telegrama adresată conducerii statului român de rectorul Academiei de Înalte Studii Comerciale și Industriale din Brașov, cu ocazia deschiderii anului universitar 1947/1948, precum și rezolvarea unor probleme organizatorice și de dotare cu material didactic. 

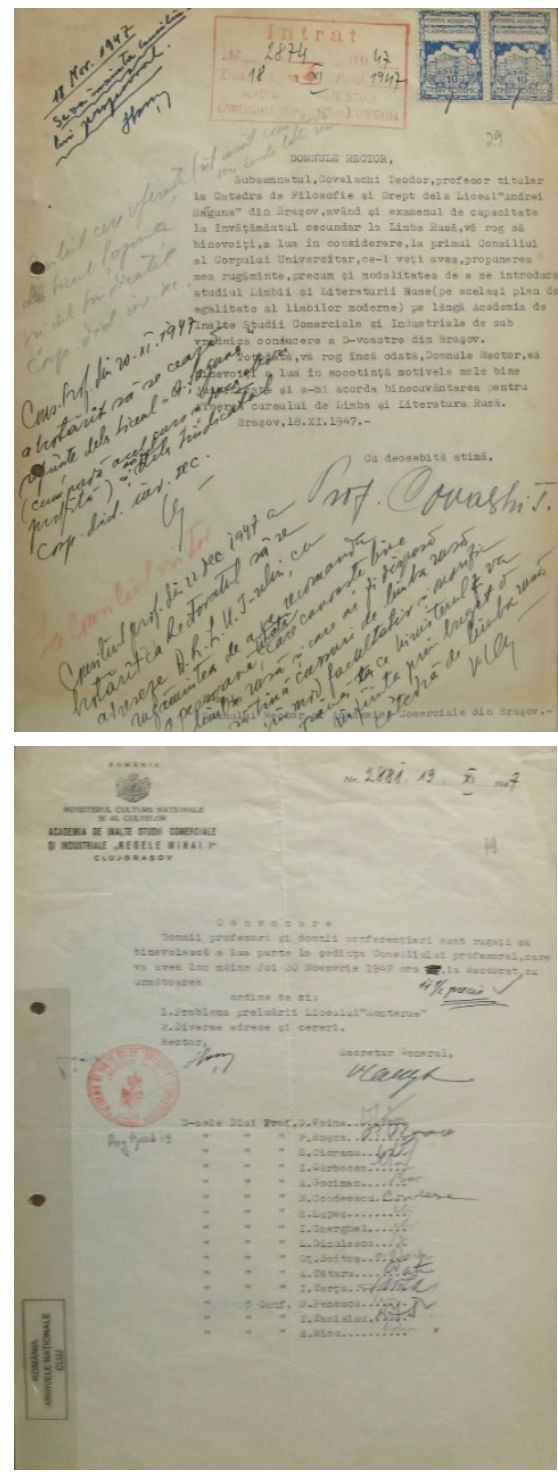
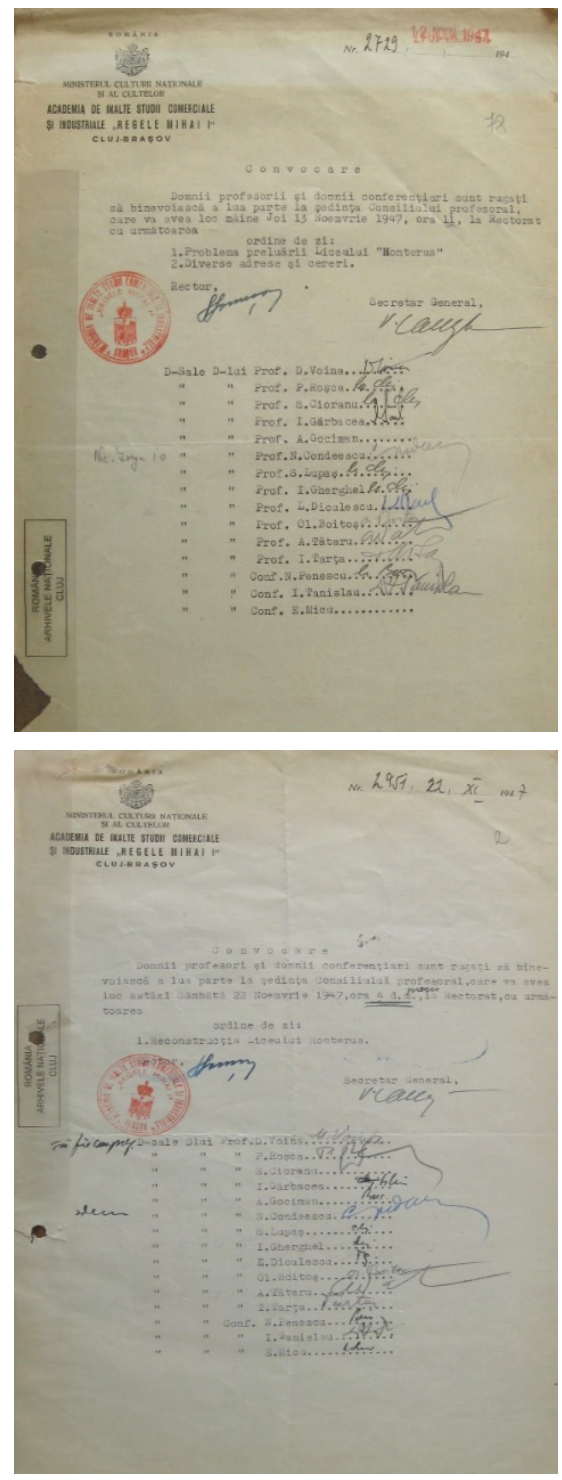

Solicitare pentru introducerea Limbii ruse în programa de învățământ a Academiei de Înalte Studii Comerciale și Industriale din Brașov, convocarea membrilor Consiliului Profesoral pentru rezolvarea preluării și amenajării Liceului Honterus în folosul Academiei, precum și rezoluțiile rectorului și ale Consiliului profesoral. 

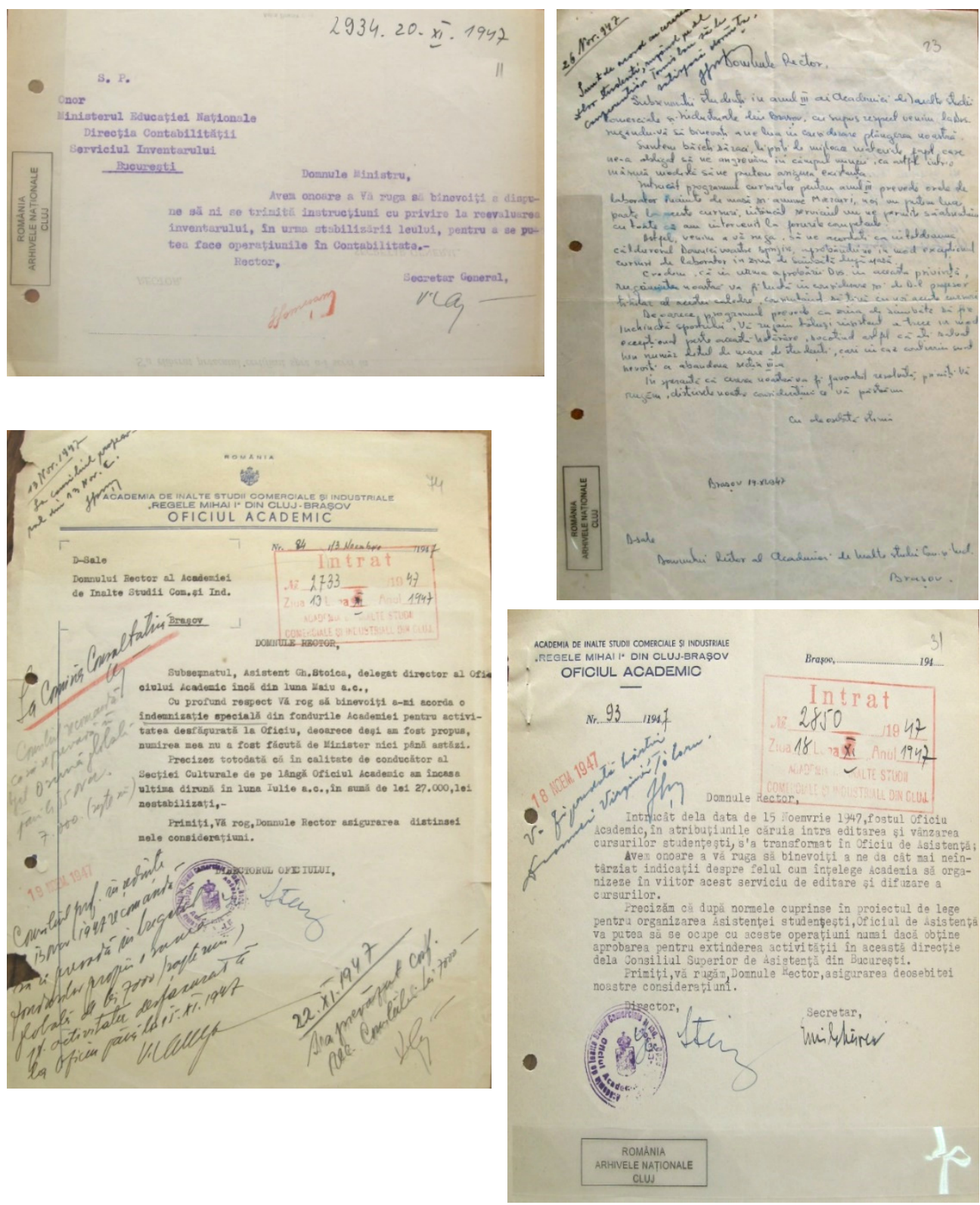

Diverse solicitări și rezoluții ale rectorului Academiei de Înalte Studii Comerciale și Industriale din Brașov, profesorul Laurian Someșan, vizând aspecte fiduciare și sociale studențești și ale corpului didactic. 

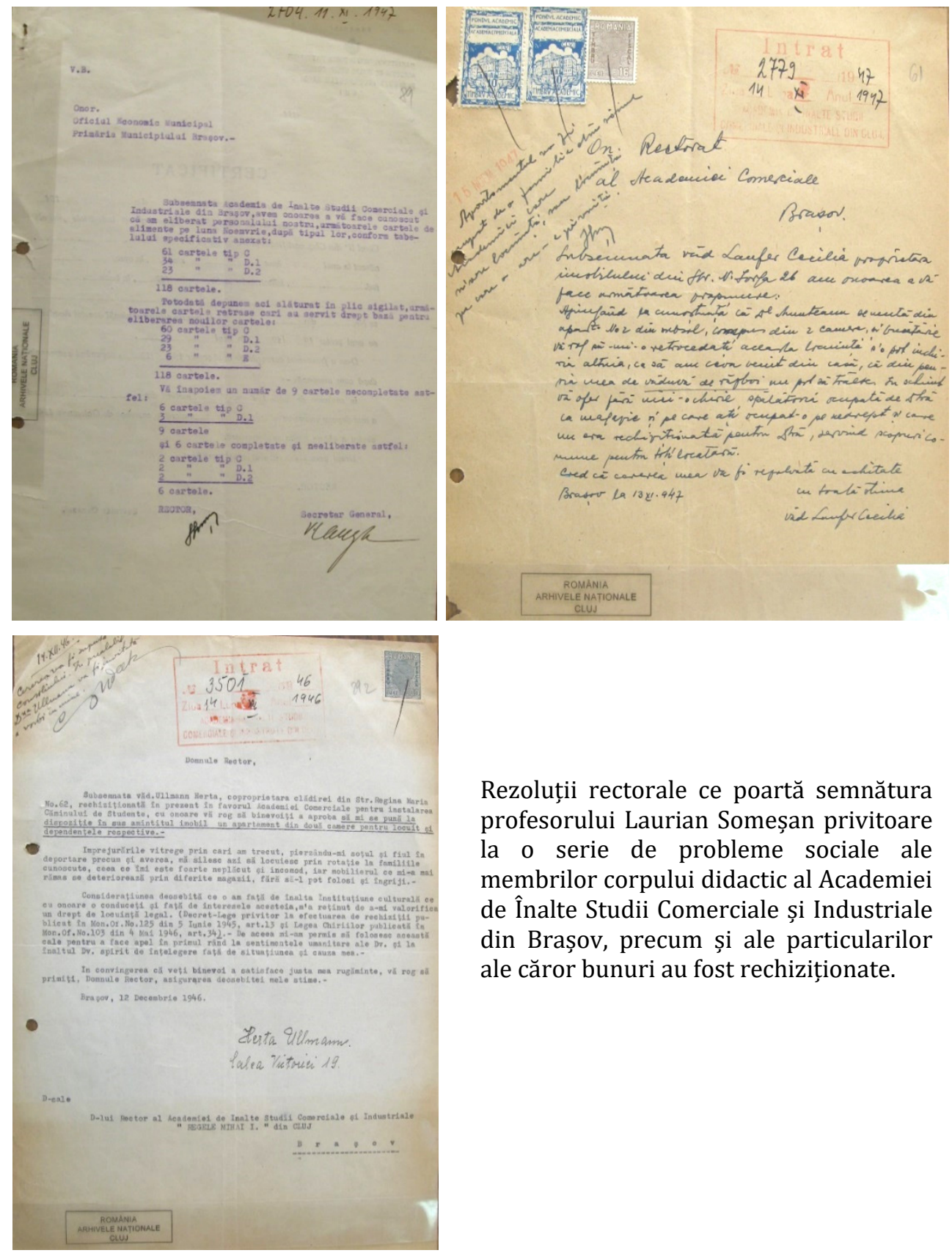

Rezoluții rectorale ce poartă semnătura profesorului Laurian Someșan privitoare la o serie de probleme sociale ale membrilor corpului didactic al Academiei de Înalte Studii Comerciale și Industriale din Brașov, precum și ale particularilor ale căror bunuri au fost rechiziționate. 


\section{EPURAREA DIN ÎNVĂȚĂMÂNTUL SUPERIOR, MARGINALIZAREA ȘI REGIMUL CARCERAL}

După instaurarea comunismului în România, profesorul Laurian Someșan a fost treptat marginalizat, suferind și rigorile regimului carceral, aidoma altor confrați de breaslă. Procesul său de marginalizare s-a desfășurat treptat. La început, el a trecut cu bine de prima etapă a epurărilor, care s-a derulat în perioada 1945-1947, când au fost înlăturați din funcțiile publice și închiși toți cei care avuseseră legătură cu regimul mareșalului Antonescu, de cele mai multe ori din „vina” deținerii unor funcții publice; unul dintre victimele de la Academia Comercială din Cluj-Brașov a fost savantul Victor JInga, pe nedrept înlăturat din funcția sa rectorală și încarcerat apoi o lungă perioadă de timp. A impresionat profund corpul profesoral, angajații și studenții Academiei Comerciale, opinia publică în general, și cazul sinuciderii profesorului Olimpiu Boitoș împreună cu soția, o cunoscută actriță a Teatrului Național din Cluj, din cauza iminenței arestării; la Brașov, soții Boitoș au locuit în același imobil cu familia Someșan, ei la etaj, iar familia Someșan la parter.

Pentru profesorul Laurian Someșan calvarul marginalizării a debutat „cu ocazia marilor epurări din 1949”, când a fost îndepărtat din învățământul superior, iar un an mai târziu, și din Institutul de Cercetări Geografice, unde era director de secție încă din 1946. Grație familiei unite, profesorul a reușit să treacă cu bine peste această primă traumă și, după aproape doi ani de „somaj”, a reușit în august 1951 să lucreze „într-un colectiv geologic al Departamentului Gospodăriei Locale, iar din ianuarie 1952, ca geolog-hidrolog în Institutul de Proiectări al Ministerului Industriei Ușoare" din Brașov (Maria Someșan, 2011, op. cit., p. 14). Ceea ce era mai rău urma să vină, anume arestarea din august 1952; dar să lăsăm pe fiica profesorului să relateze momentul, precum și desfășurarea ulterioară a evenimentelor (idem): „In noaptea de 15 august 1952 este arestat. A fost o acțiune de amploare a Securității, extinsă pe întreg teritoriul țării, căreia i-au căzut victimă un mare număr de intelectuali. [...]. După o scurtă detenție în închisoarea de la Cetățuie, timp în care familia îi este evacuată din apartamentul din str. Bogner (astăzi Aninoasa) este trimis, împreună cu întregul lot de arestați brașoveni, la celebrele lagăre de muncă forțată de la Canalul Dunăre - Marea Neagră. Ajunge în colonia care a intrat în istoria Gulagului românesc drept unul din cele mai sinistre locuri de detenție, Midia, unde, chiar în ziua sosiri, sadicul comandant al coloniei îi informa pe deținuţi că se găsesc într-un lagăr de exterminare. Pentru mulți dintre ei, amenințarea a devenit realitate. Laurian Someșan a scăpat cu viața la limită și s-a întors după doi ani, cu o notificare că a fost reținut pentru cercetări (deși în tot acest răstimp nu fusese anchetat deloc) și 
că nu a avut nicio condamnare". În momentul arestării, apartamentul a fost perchiziționat, iar membrilor familiei, respectiv soției, profesoară de Istorie la un liceu din Brașov, și fiicei Maria, studentă la Facultatea de Fizică din București, comunicându-li-se că vor fi mutate la Râșnov. După arestarea profesorului și după ce soția, Margareta Someșan a reușit să obțină permisiunea de a rămâne în oraș împreună cu fiica lor, ele au fost evacuate din casa de pe strada Bogner, unde s-a mutat ofițerul care a executat arestarea, și mutate într-o cameră situată pe strada Tânăra Gardă, unde au locuit timp de cincisprezece ani, până în 1967, când au reușit să-și cumpere apartamentul de pe Cetățuie. După arestare, înainte de a-l duce la canal, Laurian Someșan a stat încarcerat o lună în închisoarea de pe Cetățuie din Brașov, apoi l-au dus în Dobrogea.

Profesorul Ioan Iosep (2001, op. cit., p. 232), apropiat colaborator al lui Laurian Someșan din perioada lui suceveană, nuanțează momentul anului 1952, scriind că „a primit o lovitură năpraznică” când, „sub pretextul că ar fi deținut funcții importante în Partidul Național Creștin (P. N. C.), dar suspectat, după cum mi se confesa profesorul, și de orientare legionară, a fost arestat de Securitatea comunistă, fără a fi însă judecat. Nici una din acuzații nu a putut fi probată; a fost un simplu membru al P. N. C., participând la ședințele publice ale partidului, iar în ceea ce privește a doua acuzație, credem că a avut la bază o simplă speculație: corelarea specializării efectuate în Germania în anii 1938 și 1939 (când, la Berlin și München, a audiat cursuri și a participat la seminarii de geografie) cu ascensiunea fascismului [sic!, nazismului, s.n.] în Germania și a legionarismului în România și cu cercetările sale geopolitice". Peste ani, când la inițiativa profesorului Șerban Dragomirescu s-a comemorat la Brașov activitatea profesorilor universitari Laurian Someșan și Nicolae N. Popp, în cadrul simpozionului dedicat lor sub genericul „Mari cărturari brașoveni în domeniul Geoștințelor", în ambianța atât de încărcată de românism a Casei Mureșenilor, acesta spunea că „amândoi au suferit rigorile regimului totalitar comunist: au fost îndepărtați din învățământul superior, din Institutul de Cercetări Geografice al României, au cunoscut umilitoare suferințe, inclusiv regimul de detenție, fără a fi condamnați" (2011, op. cit., p. 7), iar Ioan Iosep a pus punctul pe i, spunând că au fost „aruncați în închisorile comuniste pentru motive politice inventate" (2011, op. cit., p. 25). 

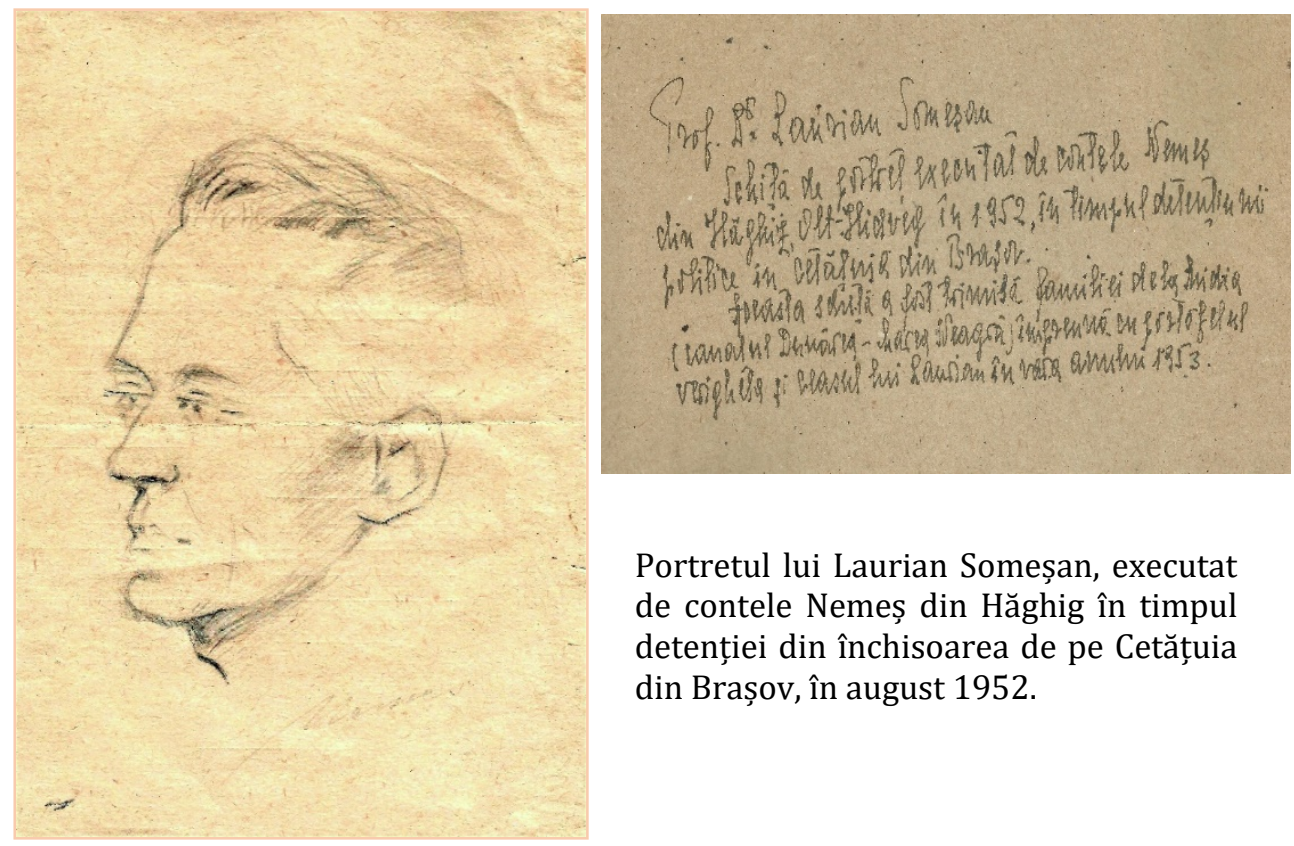

Portretul lui Laurian Someșan, executat de contele Nemeș din Hăghig în timpul detenției din închisoarea de pe Cetățuia din Brașov, în august 1952.

În perioada detenției politice a profesorului în închisoarea de pe Cetățuie de la Brașov, unde au fost aduși toți cei arestați în acele zile de la mijlocul lunii august 1952, a făcut cunoștință cu contele Nemeș, proprietarul castelului de la Hăghig care, pe o hârtie de ambalaj i-a realizat portretul; pe dosul hârtiei, s-a consemnat pentru viitorime următorul mesaj: „Schiță de portret executat de contele Nemeș din Hăghiz [Hăghig, s.n.] Olt-Hidvég în 1952, în timpul detențiunii detențiunii politice în cetățuia din Brașov. Această schiță a fost trimisă familiei de la Midia (canalul Dunărea-Marea Neagră) împreună cu portofelul, verigheta și ceasul lui Laurian în vara anului 1953". Realizarea acestui portret a fost o formă de protest a unor oameni superiori, educați, care a u răspuns la brutalitatea arestării cu instrumentele pașnice ale artei...În privința faptului că obiectele personale mai sus enumerate au fost trimise familiei profesorului Someșan în vara anului 1953, dovedește o dată în plus, cinismul securității care a pricinuit o sperietură grozavă familiei care a crezut că soțul și tatăl lor a murit în detenție!

S-a plâns vreodată public profesorul Laurian Someșan de nedreptatea care i s-a făcut? Ne răspunde la această întrebare firească Ioan Iosep care, referindu-se la ostracizarea și stigmatizarea nedreaptă la care i-a supus 
regimul totalitar pe profesorii Laurian Someșan și Nicolae Popp, pe care i-a cunoscut îndeaproape ca și coleg mai tânăr la Institutul Pedagogic din Suceava, a ținut să menționeze: „Nouă, tinerilor lor colegi suceveni, cei doi profesori nu ni s-au confesat niciodată cu privire la motivele, contextul și detaliile arestării și detenției. Și i-am înțeles: nu voiau să redeschidă rănile și să retrăiască anii dureroși care le-au zguduit viețile, le-au frânt speranțele și carierele şi le-au afectat familiile" (idem). Nu s-au plâns fiindcă știau că dreptatea este de partea lor, că au lucrat cinstit pentru țară, nu aveau să-și reproșeze ceva... Apoi să avem în vedere că intelectualitatea românească interbelică avea o demnitate dobândită prin educație și biserică, că era profund morală și animată de idei patriotice, nefiind impresionată de elementele retrograde ale societății care, cu ajutor sovietic au dobândit puterea prin fals, iar cât au fost aceste elemente de determinate, s-a văzut în sfârșitul atât de lamentabil al comunismului...

Laurian Someșan a fost un exponent reușit al acestei societăți românești, desăvârșindu-și studiile în perioada interbelică, numai prin eforturi personale, accedând în funcții și demnități numai prin meritocrație.

După eliberarea din lagărele de muncă forțată, a încercat și a reușit să reintre în învățământ, pentru că „destinderea politică care se făcea simțită în 1955 părea să-i fie favorabilă", după cum afirma Maria Someșan (2011, op. cit., p. 14), astfel că, în acele condiții „a reușit să obțină numirea la Facultatea de Silvicultură din Brassov", însă sorții nu îi surâd căci, "după 1956 (anul Revoluției din Ungaria), o nouă acțiune de epurare îi înlătură din învățământul superior pe cei politic indezirabili", astfel că doar trei ani a reușit să-și păstreze postul de conferențiar. În noile circumstanțe, se reprofilează și devine... „proiectant geotehnic la Direcția de Sistematizare și Proiectare a Construcțiilor (DSAPC) din Brașov" (idem), unde a rămas

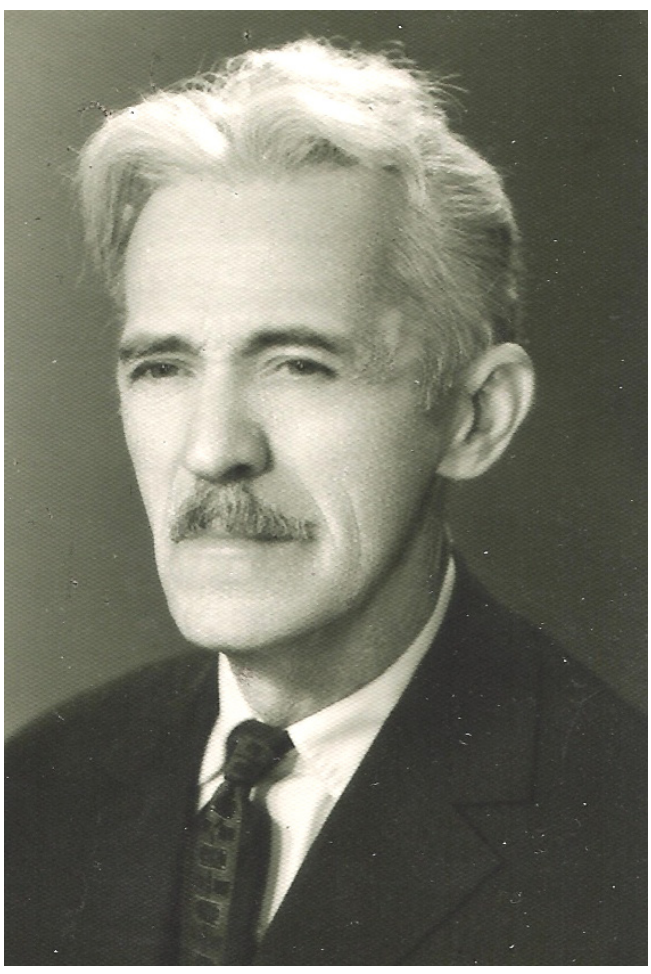

Profesorul Laurian Someșan „conferențiar” la Facultatea de Silvicultură din Brașov, în 1955. până la reabilitarea lui, odată cu 
angajarea ca lector la Institutul Pedagogic din Suceava, în 1965, astfel că, doar după șapte ani, după o nouă destindere politică, cea din 1964, a reușit să revină în învățământul superior, unde s-a titularizat în 1967, după o nouă verificare din partea serviciilor de securitate și de cadre al PCR.

Acestea sunt faptele nude, atât cele ale epurării din învățământ, ale marginalizării, cât și aceea punitivă, acte directe, fățișe; desigur că Laurian Someșan a avut de suferit și pe alte planuri, una dintre cele mai stânjenitoare și agasante pentru el fiind îngrădirea accesului la publicare. În acest sens, Maria Someșan, a consemnat: „Fiind considerat fost promotor al Geopoliticii - văzută multă vreme drept periculoasă «pseudoștiință burgheză» - i se refuză tacit timp de foarte mulți ani, uneori chiar de către foști colegi de breaslă ajunși în posturi de răspundere, dreptul de semnătură în publicațiile de specialitate. Este adevărat că și el a refuzat cu perseverență orice concesie oportunistă și nu a fost dispus să recurgă la simulări ideologice. Avea orgoliul de-a nu spune niciodată ceea ce nu credea și învățase destul de greu și de târziu să nu spună chiar tot ceea ce credea că este drept și adevărat" (idem).

Se naște în mod firesc întrebarea: a fost vinovat Laurian Someșan, numai și în parte, pentru ca să fie îndepărtat din învățământul superior, marginalizat, pentru a fi deținut în lagărele de muncă forțată? A fost vinovat Laurian Someșan că la un moment dat, când Țara i-a cerut-o, i-a apărat fruntariile pe drept dobândite? Nici vorbă! El și-a făcut datoria, așa cum i-a dictat conștiința și idealurile, care erau ale unei întregi generații, și cum fusese învățat de magistrul său, George Vâlsan. Referindu-se la motivele arestării profesorului, într-o notă de subsol (2011, op. cit., p. 25), Ioan Iosep a ținut să precizeze pentru posteritate: „Intr-o discuție purtată chiar în ziua în care avea loc ceremonia ocazionată de pensionarea profesorului Laurian Someșan (1971), rectorul de atunci, prof[esorul] V[asile] G. Ionescu, i-a mărturisit asistentului M[ihai] Iacobescu că nu cu mult timp în urmă Securitatea notificase conducerii institutului că toate acuzațiile ce îi fuseseră aduse lui Laurian Someșan s-au dovedit nefondate", fapt ce nu i s-a comunicat niciodată profesorului, autorul citat opinând "că decizia ca informația să nu-i fie adusă la cunoștință profesorului, pentru a nu-i provoca, la cei 70 de ani, un şoc fatal, a fost corectă". Referitor la acest aspect dureros din viața profesorului Someșan, la simpozionul dedicat lui și colegului său Nicolae Popp la Brașov, sub auspiciile Casei Mureșenilor, Maria Someșan a ținut să sublinieze că atunci „...când hotarele României și integritatea țării erau puse în discuție, Laurian Someșan se angajează în eforturile de apărare a intereselor românești, elaborând o serie de lucrări de geopolitică, în intenția de a demonstra că Transilvania este o regiune geografică indivizibilă și o zonă de continuitate a poporului român. Aduce argumente în sprijinul continuității elementului românesc din Transilvania și al caracterului organic al României Mari în 
articole ca La frontière occidentale de l'Etat roumain, Une carte discutable (Réponse à M. Paul Teleki), Le passé de la Transylvanie et le facteur géographique etc." (2011, op. cit., p. 12), invocând activitatea tatălui său în plan publicistic, din perioada premergătoare cataclismului politic și social al celui de-al Doilea Război Mondial când, cu argumentele științei și ale realităților evidente de pe teren, intelectualii români au răspuns pretențiilor absurde ale statelor revizioniste. În acest fel și în acele circumstanțe, „imperativele politice ale vremii i-au canalizat tot mai mult interesul pentru Geopolitică. [...]. Tocmai această activitate, desfășurată în interesul țării și în lumina idealurilor care au creat România Mare, va deveni peste un deceniu cap de acuzare împotriva sa și sursă a unui șir de persecuții politice. Ele au culminat prin detenția politică în anii de vârf ai stalinismului, destin comun unei bune părți a celor care ințeleseseră să-și asume idealurile naționale", a constatat cu amărăciune fiica profesorului.

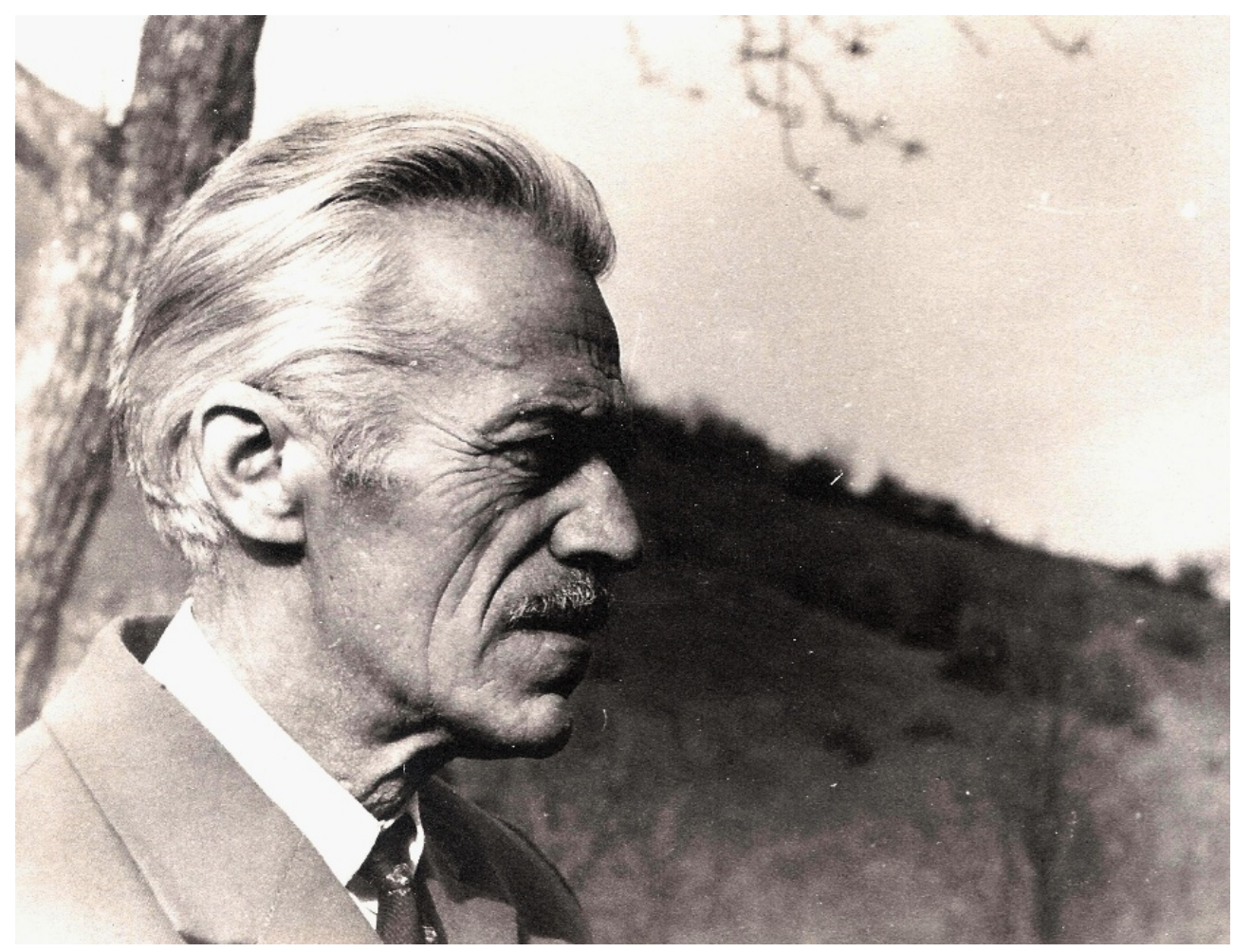

Profesorul Laurian Someșan în 1957, după ce a fost epurat de la Facultatea de Silvicultură din Brașov. 
Cu detașare, de pe culmea vârstei sale octogenare, având, la rândul domniei sale, perspectiva trecutului, fiica profesorului, Maria Someșan (2011, op. cit., p. 11), face o constatare amară, subliniind: „este locul să înregistrăm și ironia Istoriei, care a făcut ca o bună parte a celor care și-au asumat atunci aceste idealuri să fie acuzați peste nici trei decenii tocmai pentru acest fapt. Este bine să ne amintim că aproape toți protagoniștii actului Unirii de la 1 Decembrie 1918 și foarte mulți dintre acei participanți la Marea Adunare care mai erau în viață la sfârșitul celui de-al Doilea Război Mondial și-au sfârșit existența în închisorile comuniste sau, dacă le-au supraviețit au purtat până la moarte traumele detenției". Hotărât lucru, profesorul Laurian Someșan a fost pe nedrept pedepsit; ca și alte zeci și zeci de mii de intelectuali, el era incompatibil cu noua ideologie așa-zisă a omului nou, cu internaționalismul proletar care punea mai sus de interesele țării pe acelea de clasă, instaurate cu forța în țara noastră. Noii „clase politice” pusă în funcție de ocupantul sovietic doar pe criteriul obedienței față de ocupant și al atașamentului la internaționalismul proletar pentru triumful unei ideologii comuniste păguboase, îi era pur și simplu frică de elita veche, educată, pe care de-a valma a băgat-o în închisoare pentru a o extermina.

Toți cei care trecuseră prin școala românească, de la cea primară și secundară, până la aceea universitară, ca să nu mai vorbesc de școlile de ofițeri, fuseseră educați în spiritul muncii, al credinței, pentru Rege și Patrie, ca simboluri sacre ale Națiunii; se folosea în epocă sintagma: „Muncă, Credință, Rege, Națiune". Deprinși cu aceste valori sănătoase din care de desprind altele, încă din fragedă vârstă, românii le-au apărat în momentele dificile ale ocupării țării de către Armata Roșie sovietică, astfel că sute și sute de mii care i s-au împotrivit fățiș, iar intelectualii numai pentru vina de a fi intelectuali, care nu o făcuseră în mod fățiș, au fost aruncați în închisori.

Laurian Someșan, aidoma altor geografi români valoroși și cu o conștiință națională înaintată, precum Ștefan Manciulea, Gheorghe Popp, Nicolae Al. Rădulescu, Lucia Apolzan, Mihai D. David, Năstase I. Gheorghe, Ion Conea, Nicolae Dragomir, Isbășoiu Constantin, Victor Tufescu, Wachner Heinrich și mulți alții, a suferit pentru determinarea cu care a promovat și, în perioadele de cumpănă, a apărat interesele Patriei sale. 


\section{BIBLIOGRAFIE}

1. Dragomirescu, Șerban, 2011, Mari cărturari brașoveni în domeniul geoștiințelor: prof. univ. Laurian Someșan și prof. univ. Nicolae M. Popp / Great geographers from Brașov: professor Laurian Someșan and professor Nicolae M. Popp, în revista Țara Bârsei, serie nouă, numărul 10, pp. 7-8, Brașov.

2. Figes, Orlando, 2016, Revoluția Rusă, 1891-1924: tragedia unui popor, Editura Polirom, Iași.

3. Someșan, Maria, 2011, Laurian Someșan, o schiță biografică, în revista Țara Bârsei, serie nouă, numărul 10, pp. 10-15, Brașov.

4. Iosep, Ioan, 2001, In memoriam. Prof. univ. dr. Laurian Someșan (1901-1986), în Analele Universității „Ştefan cel Mare” Suceava, Secțiunea Geografie, anul X, pp. 229-240, Suceava.

5. Iosep, Ioan, 2011, Laurian Someșan și Nicolae Popp - ctitori ai învățământului geografic superior sucevean/Laurian Someșan and Nicolae Popp - the Founders of the Geography Department at the Suceava University, în revista Țara Bârsei, serie nouă, numărul 10, pp. 24-30, Brașov.

6. Pestrea, Suciu Steluța, 2011, Străzi, case, oameni din Brașov, Editura Foton, Brașov.

7. Someșan, Laurian, 1937, La frontière occidentale de l'État roumain, în Revue de Transylvanie, Anul III, nr. 2, pp.179-187, Cluj, Imprimeria Națională, București.

8. Someșan, Laurian, 1938, Une carte discutable (Réponse à M. Paul Teleki), în Revue de Transylvanie, 1938, Tome IV, no. 1-4, pp. 123-127, Cluj, Imprimeria Națională, 1939, București.

9. Someșan, Laurian, 1939, Le passé de la Transylvanie et le facteur géographique, în Revue de Transylvanie, V, 1939, 3, pp. 313-328, Cluj.

10. Suciu, Steluța, 2016, Istorii ale unor case din Brașov, în revista Astra, serie nouă, anul VII (L), nr. 1-4 (345-348)-2016, pp. 78-86, Brașov.

11. xxx, Arhivele Naționale ale României, Direcția Județeană Cluj a Arhivelor Naționale, Fond (F) 798, Dosar (D) 162, 164, 165, 171, 184, 194, 202, 203, 210, $232,246,248,249$. 